\title{
Fly Ash and Composted Biosolids as a Source of Fe for Hybrid Poplar: A Greenhouse Study
}

\author{
Kevin Lombard, ${ }^{1}$ Mick O'Neill, ${ }^{1}$ April Ulery, ${ }^{2}$ John Mexal, ${ }^{2}$ Blake Onken, ${ }^{3}$ \\ Sue Forster-Cox, ${ }^{4}$ and Ted Sammis ${ }^{2}$ \\ ${ }^{1}$ Agricultural Science Center, New Mexico State University, P.O. Box 1018, Farmington, NM 87499, USA \\ ${ }^{2}$ Department of Plant and Environmental Sciences, New Mexico State University, P.O. Box 30003, MSC 3Q, Las Cruces, \\ NM 88003-8003, USA \\ ${ }^{3}$ Lindsay Corporation, 2222 North 111th Street, Omaha, NE 68164, USA \\ ${ }^{4}$ Department of Health Science, New Mexico State University, P.O. Box 30001, MSC 3HLS, Las Cruces, NM 88003-0136, USA
}

Correspondence should be addressed to Kevin Lombard, klombard@nmsu.edu

Received 16 November 2010; Revised 8 February 2011; Accepted 10 February 2011

Academic Editor: Silvana I. Torri

Copyright () 2011 Kevin Lombard et al. This is an open access article distributed under the Creative Commons Attribution License, which permits unrestricted use, distribution, and reproduction in any medium, provided the original work is properly cited.

\begin{abstract}
Soils of northwest New Mexico have an elevated $\mathrm{pH}$ and $\mathrm{CaCO}_{3}$ content that reduces Fe solubility, causes chlorosis, and reduces crop yields. Could biosolids and fly ash, enriched with Fe, provide safe alternatives to expensive Fe EDDHA (sodium ferric ethylenediamine di-(o-hydroxyphenyl-acetate) fertilizers applied to Populus hybrid plots? Hybrid OP-367 was cultivated on a Doak sandy loam soil amended with composted biosolids or fly ash at three agricultural rates. Fly ash and Fe EDDHA treatments received urea ammonium nitrate (UAN), biosolids, enriched with $\mathrm{N}$, did not. Both amendments improved soil and plant Fe. Heavy metals were below EPA regulations, but high B levels were noted in leaves of trees treated at the highest fly ash rate. $\mathrm{pH}$ increased in fly ash soil while salinity increased in biosolids-treated soil. Chlorosis rankings improved in poplars amended with both byproducts, although composted biosolids offered the most potential at improving Fe/tree growth cheaply without the need for synthetic inputs.
\end{abstract}

\section{Introduction}

The New Mexico State University Agricultural Science Center at Farmington, San Juan County, has been exploring short rotation hybrid poplar trees for fiber and timber production, biofuel, and phytoremediation purposes. Adaptability trials involving numerous Populus crosses have produced a range of responses. Of these, Fe deficiency chlorosis (interveinal yellowing of juvenile leaves) has been observed because soil $\mathrm{pH}$ can exceed 8 with moderate to high $\mathrm{CaCO}_{3}$ levels. Under these conditions, soil iron is mostly in the form of well-crystallized iron oxides (e.g., hematite and goethite) and almost insoluble and unavailable to plants [1]. On our research plots, chelated iron fertilizer in the form of $\mathrm{Fe}$ EDDHA is applied to alleviate chlorosis symptoms. Considering that $5 \mathrm{~kg}$ Fe EDDHA material—enough to cover approximately 1 ha season ${ }^{-1}$ — costs approximately $\$ 200$, fertilizing large-scale plantations may be cost prohibitive.
On the other hand, fly ash, a byproduct from coal combustion, can provide plant-available Fe and other micronutrients [2-7]. Fly ash exits the combustion chamber with the flue gas and is captured by electrostatic precipitators, wet scrubbers, or other mechanical/chemical trap [8]. Particle sizes range from 0.01 to $100 \mu \mathrm{m}$ allowing a large amount of surface area to mass [9]. Nearly 3.9 million $\mathrm{Mg}$ of coal combustion products (ash + flue gas desulfurization products) are produced in San Juan County each year by two coal fired generating plants, and both power plants are actively seeking recycling options (Salisbury, 2003, personal communication).

Biosolids (dewatered sewage sludge) also increase levels of plant-available Fe on calcareous soils $[6,10,11]$ and are a source of other plant-essential elements including $\mathrm{N}$ and $\mathrm{P}$ $[12,13]$. Iron enhancement in biosolids results from multiple factors at the wastewater treatment facility. When washed into treatment plants through storm runoff, iron oxides can 
be reduced and reprecipitated as weakly crystalline plantavailable iron phosphates [14]. Salts of $\mathrm{FeCl}_{3}$ or $\mathrm{FeCl}_{2}$ used to capture phosphorus from the waste stream during the treatment process also increase the iron phosphate content of biosolids [14, 15]. The city of Albuquerque, $290 \mathrm{~km}$ southeast of Farmington, produces $142 \mathrm{Mg}$ of biosolids per day and is a regional leader in seeking land-use disposal and marketing options of processed, composted biosolids [16].

Environmental consequences for both byproducts also have been documented. Fly ash can contain elevated levels of heavy metals, increase boron to toxic levels, can act as liming agents because of their high $\mathrm{Ca} / \mathrm{Mg}$ content, and can increase soil salinity $[17,18]$. Biosolids also have the potential to increase salinity, heavy metals, and persistent organic pollutants such as antibiotics, and personal care products that enter the waste stream $[19,20]$. If an environmentally responsible use can be established, recycling of these byproducts to agricultural lands may present an attractive disposal alternative because of the large land area devoted to crop production within a relatively short distance from the power plant or wastewater treatment facilities in the Farmington area. The objectives of this study were to pilot test the application of fly ash and composted biosolids at three rates to a high $\mathrm{pH}$ soil from Northwest, NM. Specific objectives were to

(1) determine if Fe nutrition of soil and the growth of hybrid poplar clone OP-367 could be improved by amending soil with each amendment,

(2) examine potential environmental issues, including heavy metal contamination, salinity, and $\mathrm{pH}$ changes in the soil, caused by each amendment.

\section{Materials and Methods}

\subsection{Soil and Treatments}

2.1.1. 2004 Study Soil and Treatments. A Doak sandy loam (fine-loamy, mixed, mesic Typic Haplargid) [21] was collected from the top $20-25 \mathrm{~cm}$ of the plow layer from an agricultural field located at the New Mexico State University Agricultural Science Center, Farmington (lat. $36^{\circ} 41^{\prime} 0^{\prime \prime}$ $\mathrm{N}$; long. $108^{\circ} 18^{\prime} 36^{\prime \prime} \mathrm{W}$; elevation $1,700 \mathrm{~m}$ ). Soil was sieved through $6-\mathrm{mm} \times 6-\mathrm{mm}$ mesh to remove clods then transported to the NMSU Fabian Garcia horticulture farm greenhouse complex (Las Cruces, NM). Prior to container filling, a fiberglass mesh screen was used to line standard 7.5 L nursery containers to prevent soil loss through drainage holes. Each container was filled to a dry weight of $9 \mathrm{~kg}$. Once filled, the surface area at the top of each container was $366 \mathrm{~cm}^{2}$.

Fly ash was collected from the APS Four Corners Power Plant (Farmington, NM). Fly ash at the power plant is stored in a lined ash impoundment area adjacent to plant. Composted biosolids were collected from the City of Albuquerque, NM Pilot Composting Facility. The biosolids were a 1:3 ratio of dewatered sewage sludge mixed with chipped yard waste that were composted in large windrows at $57^{\circ} \mathrm{C}$ for six weeks. The composting process reduces pathogen concentrations to comply with USEPA standards for "Class A" classification [16]. After composting, the biosolids were drum sieved before trucking to Farmington. The fly ash required no sieving.

Composted biosolids and fly ash treatments were applied to the nursery containers February 24, 2005 at two agricultural rates: $22.75 \mathrm{Mg} \mathrm{ha}^{-1}$ (82.1 g byproduct per container) and $45.5 \mathrm{Mg} \mathrm{ha}^{-1}$ (164 g byproduct per container). A third rate was applied based on two criteria: (1) the amount of Fe in the Farmington soil after a DTPA- (diethylenetriaminepentaacetic acid-) extractable Fe baseline soil test was conducted and (2) the percent available Fe in each amendment that could be applied to the soil as a fertilizer to correct a potential Fe deficiency. The complete baseline soil chemical analysis used to determine DTPA application rates was established earlier for both byproducts and is presented in Table 1. The DTPA Fe content of the Farmington soil was $1.2 \mathrm{mg} \mathrm{kg}^{-1}$. For soils with a test report of $0.0-2.5 \mathrm{mg} \mathrm{kg}^{-1}$ Fe, Jones and Jacobsen [22] recommend an application rate of $4.5 \mathrm{k} \mathrm{Feha}^{-1}$ in order to overcome Fe deficiency in susceptible crops. The DTPA-extractable iron in the fly ash was $0.00609 \% \mathrm{Fe}$ and $0.0329 \% \mathrm{Fe}$ for the biosolids. Expressed as fractions, DTPA values determined for each byproduct were used as divisors to the $4.5 \mathrm{~kg} \mathrm{Fe} \mathrm{ha}{ }^{-1}$ recommendation which yielded the equivalent of $74 \mathrm{Mg}$ of fly ash ha ${ }^{-1}$ (270.5 g applied per container) and $14 \mathrm{Mg}$ biosolids $\mathrm{ha}^{-1}$ (50.1 g per container) application rates. These were the highest and lowest rates for fly ash and composted biosolids, respectively. Treatments were incorporated by removing the top $10 \mathrm{~cm}$ of soil from each nursery container, placing the contents into a plastic bucket, and mixing in the amendment before returning the contents to the nursery container. An Fe fertilizer check, Sprint Sequestrene 138 (use of a trademarked product does not imply an endorsement by the NMSU Agricultural Experiment Station), 6\% EDDHA chelated Fe (Becker Underwood, Ames Iowa), was applied as a soil drench once at week three at an application rate of $4.5 \mathrm{~kg} \mathrm{Fe} \mathrm{ha}^{-1}$ ( $275 \mathrm{mg}$ Fe EDDHA per container). The application rate was based on the soil test report and percent available $\mathrm{Fe}$ in the product $(6 \%)$ to supply the literature recommendations as described previously. Unamended soil served as the control.

2.2. Plant Material. Hybrid poplar OP-367 (Populus deltoides $\times P$. nigra) is a commercial hybrid that performs well in Farmington but benefits from supplemental Fe. Uniform $30 \mathrm{~cm}$ long cuttings obtained from Broadacres Nursery (Hubbard, OR) were soaked for 3 days in tap water before transplanting (February 27, 2005) directly into nursery containers.

2.3. Other Cultural Practices. Greenhouse temperatures averaged $16^{\circ} \mathrm{C}(\mathrm{min})$ and $41^{\circ} \mathrm{C}(\max )$. Containers were kept at or below field capacity and were not leached to examine the potential for salt buildup in the soil. The total amount of water applied to each container over the course of the study was $647 \mathrm{~mm}$. 
TABLE 1: Selected chemical properties of Albuquerque biosolids and APS fly ash.

\begin{tabular}{|c|c|c|}
\hline Characteristic & Composted biosolids & Fly ash ${ }^{\mathrm{b}}$ \\
\hline $\mathrm{pH}(1: 2)^{\mathrm{c}}$ & 7.4 & 12.4 \\
\hline $\mathrm{EC}\left(\mathrm{dS} \mathrm{m}^{-1}\right)^{\mathrm{d}}$ & 14.0 & 6.7 \\
\hline $\operatorname{SAR}\left(\mathrm{mmol} \mathrm{L}^{-1}\right)^{\mathrm{d}}$ & 4.75 & 2.04 \\
\hline $\mathrm{NO}_{3}-\mathrm{N}\left(\mathrm{mg} \mathrm{kg}^{-1}\right)^{\mathrm{e}}$ & 71.3 & 2.71 \\
\hline TKN $\left(\mathrm{mg} \mathrm{kg}^{-1}\right)^{\mathrm{f}}$ & 1850.0 & NT \\
\hline $\mathrm{P}\left(\mathrm{mg} \mathrm{kg}^{-1}\right)^{\mathrm{c}}$ & 231.3 & 17.0 \\
\hline $\mathrm{K}\left(\mathrm{mg} \mathrm{kg}^{-1}\right)^{\mathrm{c}}$ & 5723.3 & 11.7 \\
\hline $\mathrm{Zn}\left(\mathrm{mg} \mathrm{kg}^{-1}\right)^{\mathrm{c}}$ & 44.9 & 0.6 \\
\hline $\mathrm{Fe}\left(\mathrm{mg} \mathrm{kg}^{-1}\right)^{\mathrm{c}}$ & 420.3 & 78.4 \\
\hline Fe by DTPA $\left(\mathrm{mg} \mathrm{kg}^{-1}\right)^{\mathrm{z}}$ & 329.0 & 60.90 \\
\hline $\operatorname{Mn}\left(\mathrm{mg} \mathrm{kg}^{-1}\right)^{\mathrm{c}}$ & 20.6 & 8.1 \\
\hline $\mathrm{Cu}\left(\mathrm{mg} \mathrm{kg}^{-1}\right)^{\mathrm{c}}$ & 15.0 & 1.2 \\
\hline $\mathrm{Ca}\left(\mathrm{mg} \mathrm{kg}^{-1}\right)^{\mathrm{c}}$ & 3557.0 & 5650.0 \\
\hline $\operatorname{Mg}\left(\mathrm{mg} \mathrm{kg}^{-1}\right)^{\mathrm{c}}$ & 657.7 & 31.0 \\
\hline $\mathrm{Na}\left(\mathrm{mg} \mathrm{kg}^{-1}\right)^{\mathrm{c}}$ & 855.3 & 53.6 \\
\hline $\mathrm{S}\left(\mathrm{mg} \mathrm{kg}^{-1}\right)^{\mathrm{e}}$ & 529.5 & 306.7 \\
\hline $\mathrm{Al}\left(\mathrm{mg} \mathrm{kg}^{-1}\right)^{\mathrm{e}}$ & 807.2 & 348.7 \\
\hline As $\left(\mathrm{mg} \mathrm{kg}^{-1}\right)^{\mathrm{e}}$ & 18.5 & 10.3 \\
\hline $\mathrm{B}\left(\mathrm{mg} \mathrm{kg}^{-1}\right)^{\mathrm{e}}$ & 40.1 & 59.5 \\
\hline $\mathrm{Ba}\left(\mathrm{mg} \mathrm{kg}^{-1}\right)^{\mathrm{e}}$ & 211.8 & 904.1 \\
\hline $\mathrm{Be}\left(\mathrm{mg} \mathrm{kg}^{-1}\right)^{\mathrm{e}}$ & ND & ND \\
\hline $\mathrm{Cd}\left(\mathrm{mg} \mathrm{kg}^{-1}\right)^{\mathrm{e}}$ & 2.3 & 1.3 \\
\hline Co $\left(\mathrm{mg} \mathrm{kg}^{-1}\right)^{\mathrm{e}}$ & 3.4 & 0.8 \\
\hline $\mathrm{Cr}\left(\mathrm{mg} \mathrm{kg}^{-1}\right)^{\mathrm{e}}$ & 13.9 & 2.9 \\
\hline $\operatorname{Mo}\left(\mathrm{mg} \mathrm{kg}^{-1}\right)^{\mathrm{e}}$ & ND & ND \\
\hline $\mathrm{Ni}\left(\mathrm{mg} \mathrm{kg}^{-1}\right)^{\mathrm{e}}$ & 8.6 & 1.9 \\
\hline $\mathrm{Pb}\left(\mathrm{mg} \mathrm{kg}^{-1}\right)^{\mathrm{e}}$ & 18.8 & 5.0 \\
\hline $\mathrm{Se}\left(\mathrm{mg} \mathrm{kg}^{-1}\right)^{\mathrm{e}}$ & ND & ND \\
\hline $\mathrm{Tl}\left(\mathrm{mg} \mathrm{kg}^{-1}\right)^{\mathrm{e}}$ & $\mathrm{ND}$ & ND \\
\hline $\mathrm{V}\left(\mathrm{mg} \mathrm{kg}^{-1}\right)^{\mathrm{e}}$ & 22.1 & 8.4 \\
\hline $\mathrm{Bi}\left(\mathrm{mg} \mathrm{kg}^{-1}\right)^{\mathrm{e}}$ & ND & ND \\
\hline $\mathrm{Li}\left(\mathrm{mg} \mathrm{kg}^{-1}\right)^{\mathrm{e}}$ & 8.6 & 3.8 \\
\hline $\mathrm{Sr}\left(\mathrm{mg} \mathrm{kg}^{-1}\right)^{\mathrm{e}}$ & 163.8 & 37.9 \\
\hline $\mathrm{Si}\left(\mathrm{mg} \mathrm{kg}^{-1}\right)^{\mathrm{e}}$ & 322.7 & 308.7 \\
\hline $\mathrm{Ag}\left(\mathrm{mg} \mathrm{kg}^{-1}\right)^{\mathrm{e}}$ & 5.2 & ND \\
\hline
\end{tabular}

${ }^{\mathrm{a}}$ Mean of 6 samples for $\mathrm{pH}, \mathrm{P}, \mathrm{K}, \mathrm{Zn}, \mathrm{Fe}, \mathrm{Mn}, \mathrm{Cu}, \mathrm{Ca}, \mathrm{Mg}$, and $\mathrm{Na}$.

${ }^{b}$ Mean of 3 samples for S, Al, As, B, Ba, Be, Cd, Co, Cr, Mo, Ni, Pb, Se, Tl, V, $\mathrm{Bi}, \mathrm{Li}, \mathrm{Sr}, \mathrm{Si}$, and $\mathrm{Ag}$.

${ }^{\mathrm{c}}$ Analyzed at Soil Chemistry Research Laboratory, NMSU, Las Cruces, NM.

${ }^{\mathrm{d}}$ Analyzed at Agricultural Testing and Research Laboratory, NAPI, Farmington, NM.

${ }^{\mathrm{e}}$ Analyzed at the NMSU Soil, Water, and Air Testing Laboratory, Las Cruces, NM.

${ }^{\mathrm{f}}$ Literature value supplied by Glass (personal communication, 2006).

$\mathrm{ND}=$ not detected. $\mathrm{NT}=$ not tested.

The control soil has a low $\mathrm{N}$ content (less than $1 \%$ organic matter). In addition, $\mathrm{N}$ is volatilized during combustion, making fly ash even lower in $\mathrm{N}$ content. Therefore, the fly ash- and Fe EDDHA-treated trees received the equivalent of $90 \mathrm{~kg} \mathrm{Nha}^{-1} \mathrm{~N}$ (split into 14 application times spread over the course of the study, applied to trees in the irrigation water) in the form of urea ammonium nitrate (UAN 32$0-0)$ in order to maintain similar values of $\mathrm{N}$ in all treatments. This was necessary because the composted biosolids contained $85.5 \mathrm{~kg} \mathrm{~N} \mathrm{ha}^{-1}$ when applied at the $44.5 \mathrm{Mg} \mathrm{ha}^{-1}$ rate determined from $\mathrm{NO}_{3}-\mathrm{N}$ using the ion-specific electrode method [23] and Kjeldahl N measured by the City of Albuquerque (Glass, 2006 personal communication) (Table 1).

2.4. Chlorophyll Analysis. Leaf chlorophyll content was monitored using a handheld Minolta SPAD- (soil plant analysis development-) 502 meter. The SPAD meter nondestructively measures transmittance of the leaf in red and infrared wavelengths (650 and $940 \mathrm{~nm}$, resp.) giving a unitless leaf "greenness" value [24]. As SPAD values increase, leaf chlorosis decreases. For the clone OP-367, SPAD values were previously shown to correlate well with $\mathrm{Fe}\left(r^{2}=0.58\right)$ and total chlorophyll analyzed by HPLC $\left(r^{2}=0.85\right)$ [25]. SPAD readings were made on April 12, and June 22 by measuring the first 10 fully expanded leaves (beginning 5-6 nodes down from the apical bud) on each tree.

2.5. Postharvest Analysis. The study was terminated July 6,2005 at which point leaves were removed from each tree and passed through a leaf area meter. Leaves were decontaminated of Fe sources from dust/soil by dipping in a $0.01 \%$ phosphate-free detergent bath $\left(0.1 \mathrm{~mL}\right.$ detergent $\mathrm{L}^{-1}$ tap $\mathrm{H}_{2} \mathrm{O}$ ) [26] followed by rinsing with tap water under low pressure to remove soap residues. Leaves were then dipped into two baths of distilled water, bagged, dried for 24 hours at $70^{\circ} \mathrm{C}$, and then weighed.

Stems were severed $2 \mathrm{~cm}$ from the top of the original cutting and measured for basal diameter and overall length. Soil was removed from the root ball (roots plus original cutting) then sieved through a $3 \mathrm{~mm} \times 3 \mathrm{~mm}$ mesh to remove root pieces. Roots were then dipped in six water baths to remove residual soil. Roots were then severed from the original cutting and rinsed under low pressure. Stems and roots were then dried separately at $70^{\circ} \mathrm{C}$ for 72 hours before weighing.

2.5.1. Plant $\mathrm{Fe}$ and $\mathrm{N}$ Analysis. Dried leaves and stem material were ground to a fine powder using a stainless steel coffee grinder (cleaned thoroughly between samples) and stored in snap cap vials at room temperature until chemical analysis. Plant Fe was extracted with $20 \%$ trace metal grade $\mathrm{HCl}$ after dry ashing [27] and analyzed by inductively coupled plasma-optical emission spectroscopy (ICP-OES; Perkin-Elmer Optima 4300 DV ICP-OES). Plant total nitrogen (TN) was determined directly by combustion (LECO TruSpec CNS).

2.5.2. Plant Tissue Heavy Metal Analysis. Following the method described by Miller [28], microwave-assisted acid digestion using Teflon pressure digestion vessels was used to extract $\mathrm{Cr}, \mathrm{Pb}, \mathrm{Se}, \mathrm{As}, \mathrm{Ag}, \mathrm{Ba}$, and $\mathrm{Cd}$ from leaves. Acid digests were then analyzed by ICP-OES. All plant tissue macro elements, $\mathrm{Fe}, \mathrm{B}$, and heavy metals are expressed on a dry weight basis. 
2.5.3. Soil Analysis. Soil was analyzed for $\mathrm{pH}(1: 2$, soil : water), extractable $\mathrm{P}$, and Fe by ammonium bicarbonate-DTPA $\left(1.0 \mathrm{~mol} \mathrm{~L}^{-1} \mathrm{NH}_{4} \mathrm{HCO}_{3}+0.005 \mathrm{~mol} \mathrm{~L}^{-1}\right.$ DTPA at $\mathrm{pH}$ 7.6) [29]. Extracts were analyzed by ICP-OES. Soil $\mathrm{NO}_{3}-\mathrm{N}$ was analyzed using the ion specific electrode method [23]. Electrical conductivity (EC) and sodium adsorption ratio (SAR) were measured on saturated paste extracts. Soil $\mathrm{Cr}, \mathrm{Pb}, \mathrm{Se}, \mathrm{As}, \mathrm{Ag}, \mathrm{Ba}$, and $\mathrm{Cd}$ concentrations were determined by ICP-OES following the USEPA 3051A [30] microwave-assisted acid digestion method for soil samples.

All laboratory analyses were conducted at the Navajo Agricultural Products Industry (NAPI) Agricultural Testing and Research Laboratory (Farmington, NM), NMSU Plant and Environmental Sciences Soils Research group laboratory (Las Cruces, NM), and the NMSU Soil, Water, and Air Testing (SWAT) laboratory.

2.6. Experimental Design and Statistical Analysis. The study was a randomized complete block design on two benches to compensate for temperature gradients within the greenhouse. There were eight containers per each treatment. Containers were redistributed once per week within blocks on the benches to help ensure that all trees received equal amounts of light exposure.

Analysis of variance was done in SAS (Cary, NC) using the PROC Mixed statement. All pairwise comparisons were made when significant differences were observed using Fisher's protected LSD at an alpha 0.05 level calculated by the method described by Littell et al. [31]. Concerning plant elements (Fe, N, B, and $\mathrm{Ba}$ ), when significant accumulations of these elements were found in stems and leaves, the statistics were performed on the total plant accumulation (leaves + stems). In the case when no significant differences were detected in stems but were in leaves, only leaves are reported to simplify the data reporting. Correlation analysis using the PROC CORR command was performed to determine linear relationships between plant growth and environmental/plant toxicity parameters (i.e., pH, EC, SAR, and boron).

Codes for biosolid treatments are referenced the following way: ACB 22.75, ACB 44.5 (for Albuquerque composted biosolids at $22.75 \mathrm{Mg} \mathrm{ha}^{-1}$ and $44.5 \mathrm{Mgha}^{-1}$ application rates, resp.), ACB DTPA (biosolids applied at a rate based upon its DTPA extractable, plant-available Fe). Codes for fly ash plus urea ammonium nitrate fertilizer treatments are referenced as FA $22.75+\mathrm{UAN}$, FA $44.5+\mathrm{UAN}$, and FA DTPA + UAN (fly ash applied at a rate based upon its DTPA extractable, plant-available Fe). The Fe EDDHA plus urea ammonium nitrate fertilizer treatment is referenced as Fe $\mathrm{EDDHA}+\mathrm{UAN}$.

\section{Results and Discussion}

\subsection{Soil/Plant Nutrient Status and Tree Growth after Amending with Byproducts}

3.1.1. Soil Fe, Chlorosis, and Tissue Fe Responses. Even though soil $\mathrm{Fe}$ in OP-367 trees receiving Fe EDDHA + UAN was
TABLE 2: Soil $\mathrm{NO}_{3}-\mathrm{N}, \mathrm{P}$, and Fe a Doak sandy loam after amending with Fe EDDHA + UAN (urea ammonium nitrate), fly ash + UAN, and composted biosolids ( $n=8$ per treatment). Means with the same letter are not significantly different at $\alpha=0.05$ level.

\begin{tabular}{lccc}
\hline Treatments $^{\mathrm{a}}$ & $\begin{array}{c}\mathrm{Fe} \\
(\mathrm{mg} \mathrm{kg}\end{array}$ & $\begin{array}{c}\mathrm{NO}_{3}-\mathrm{N} \\
\left(\mathrm{mg} \mathrm{kg}^{-1}\right)\end{array}$ & $\begin{array}{c}\mathrm{P} \\
\left(\mathrm{mg} \mathrm{kg}^{-1}\right)\end{array}$ \\
\hline Control & $4.44 \mathrm{~d}$ & $2.3 \mathrm{c}$ & $9.39 \mathrm{~d}$ \\
Fe EDDHA + UAN & $4.84 \mathrm{~d}$ & $3.4 \mathrm{a}$ & $8.55 \mathrm{~d}$ \\
ACB DTPA & $16.63 \mathrm{c}$ & $2.4 \mathrm{c}$ & $23.23 \mathrm{c}$ \\
ACB 22.75 & $22.13 \mathrm{~b}$ & $2.5 \mathrm{bc}$ & $30.71 \mathrm{~b}$ \\
ACB 44.5 & $37.09 \mathrm{a}$ & $3.3 \mathrm{ab}$ & $52.05 \mathrm{a}$ \\
FA 22.75 + UAN & $5.27 \mathrm{~d}$ & $3.8 \mathrm{a}$ & $8.87 \mathrm{~d}$ \\
FA 44.5 + UAN & $5.51 \mathrm{~d}$ & $3.5 \mathrm{a}$ & $8.90 \mathrm{~d}$ \\
FA DTPA + UAN & $6.48 \mathrm{~d}$ & $3.7 \mathrm{a}$ & $8.59 \mathrm{~d}$ \\
\hline Mean & 12.80 & 3.1 & 18.79 \\
LSD & 3.28 & 0.82 & 2.56 \\
$F$ Value & 104.09 & 4.64 & 306.1 \\
Pr $>$ F & $<.0001$ & 0.0004 & $<.0001$ \\
\hline
\end{tabular}

${ }^{a}$ Codes for biosolid treatments are referenced the following way: ACB 22.75, ACB 44.5 (for Albuquerque composted biosolids at $22.75 \mathrm{Mg} \mathrm{ha}^{-1}$ and $44.5 \mathrm{Mg} \mathrm{ha}^{-1}$ application rates, resp.), ACB DTPA (biosolids applied at a rate based upon its DTPA extractable, plant-available Fe; equivalent to $14 \mathrm{Mgha}^{-1}$ ). Codes for fly ash plus urea ammonium nitrate fertilizer treatments are referenced as FA $22.75+$ UAN, FA $44.5+$ UAN, and FA DTPA + UAN (fly ash applied at a rate based upon its DTPA extractable, plant-available Fe; equivalent to $74 \mathrm{Mgha}^{-1}$ ). The Fe EDDHA plus urea ammonium nitrate fertilizer treatment is referenced as Fe EDDHA + UAN.

no different than the control (Table 2), these trees had the highest mean SPAD values (41.2 SPAD units; $P<.0001$ ) and highest plant Fe $\left(38.3 \mathrm{mg} \mathrm{kg}^{-1} ; P<.0001\right.$; Figure 1$)$. Fly ash + UAN increased soil Fe concentration 18-46\%, though these increases were also no different from the control soil (Table 2). However, chlorophyll and plant Fe in fly ash + UAN treatments increased in leaves according to the application rate in the following manner: SPAD values were highest in the FA DTPA + UAN rate (36.9 SPAD units with a $64 \%$ increase in plant $\mathrm{Fe}$ ), followed by the FA $44.5 \mathrm{Mg} \mathrm{ha}^{-1}+$ UAN rate (SPAD value 34.7 and $64 \%$ increase in plant $\mathrm{Fe}$ ) and FA $22.75 \mathrm{Mg} \mathrm{ha}^{-1}+\mathrm{UAN}$ rate (SPAD value 32.8 and $43 \%$ increase in plant Fe; Figure 1).

The increases in plant Fe with the presumed boost in SPAD values were consistent with carrot when grown at a fly ash landfill site [32]. We have shown in previous studies that both $\mathrm{Fe}$ and $\mathrm{N}$ play a role in influencing SPAD values for the hybrid OP-367 [25]. Fly ash- and Fe EDDHA + UAN-treated poplars were given the same amount of UAN during the study, holding $\mathrm{N}$ constant. Acid-forming fertilizers containing $\mathrm{NH}_{4}{ }^{+}$, such as UAN, are known to lower the $\mathrm{pH}$ of the rhizosphere, making $\mathrm{Fe}$ and other microelements more plant-available in alkaline soils [33-35]. So the addition of UAN probably had a role in increasing plant Fe and SPAD values in the Fe EDDHA- and fly ashtreated trees.

Biosolids, on the other hand, significantly improved soil Fe contents by $275-700 \%$ above the control soil $(P<$ .0001 ; Table 2), a response consistent with other studies 


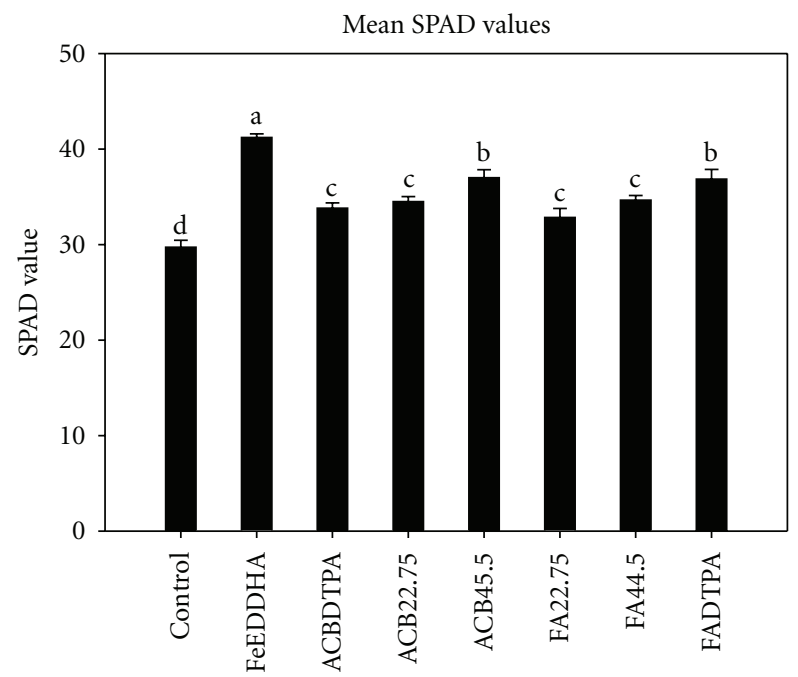

(a)

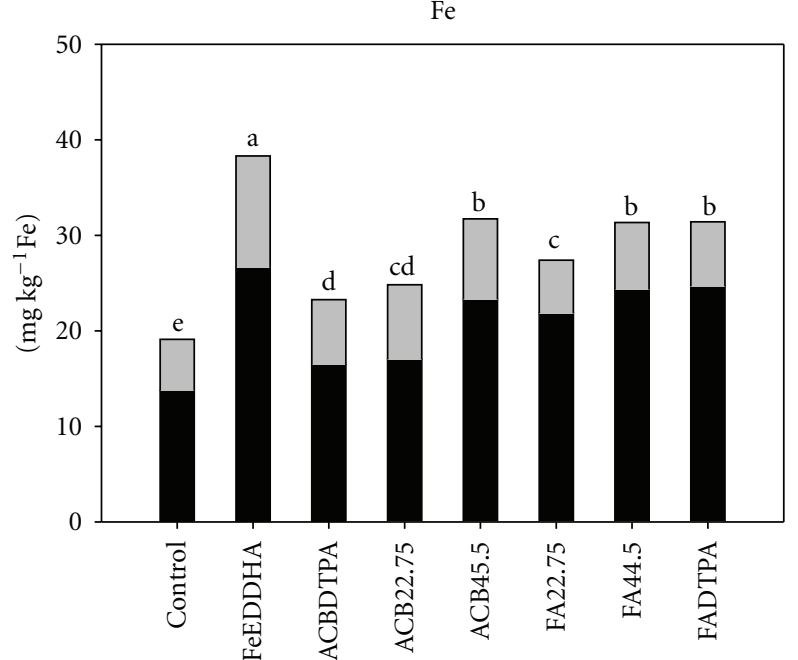

(b)

TN

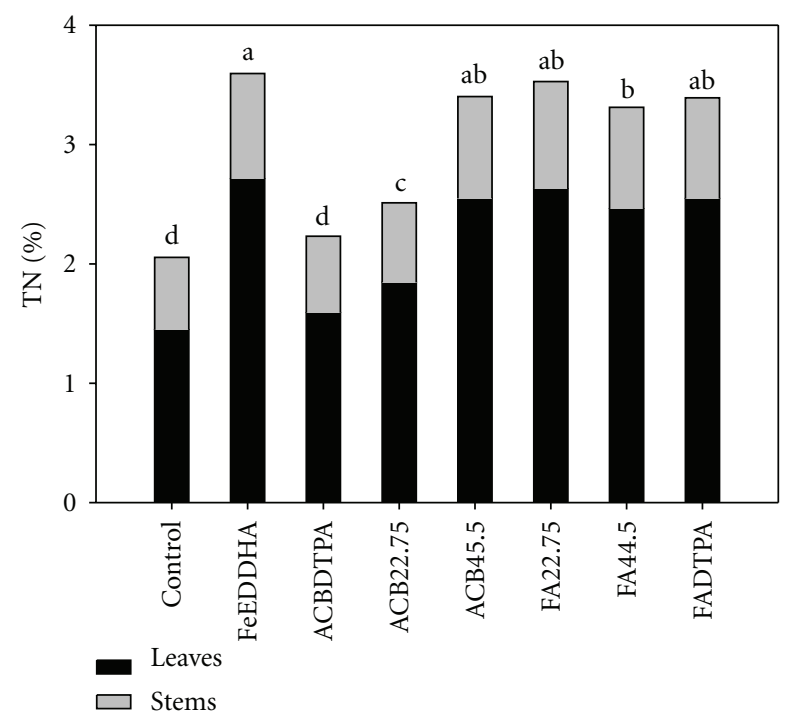

(c)

Figure 1: SPAD values (a), plant Fe (b), and total plant N (c) of the hybrid poplar clone OP-367 cultivated in soil amended with Fe EDDHA + UAN (urea ammonium nitrate), fly ash + UAN, and composted biosolids. SPAD means are from two measurement periods. Means with the same letter are not significantly different at $\alpha=0.05$ level for combined leaf and stem material. Refer to Experimental Design and Statistical Analysis section for treatment codes.

when wastewater has been treated with $\mathrm{FeCl}$ salts and the subsequent biosolids are applied to calcareous soils $[6,11]$. These trees also had improved leaf greenness and plant $\mathrm{Fe}$ (leaves plus stems) in the following way: the ACB DTPA $\left(14 \mathrm{Mg} \mathrm{ha}^{-1}\right)$ gave SPAD values of 33.8 and a $22 \%$ plant Fe improvement while the ACB $22.75 \mathrm{Mg} \mathrm{ha}^{-1}$ treatment raised SPAD values to 34.5 and plant $\mathrm{Fe}$ by $30 \%$ above control trees (Figure 1). Composted biosolids applied at the $44.5 \mathrm{Mg} \mathrm{ha}^{-1}$ rate resulted in a $66 \%$ increase in plant Fe above the control $(P<.0001)$. Although statistically lower than the Fe EDDHA+UAN treated trees, SPAD values in the ACB $44.5 \mathrm{Mg} \mathrm{ha}^{-1}$ trees increased to $37.0,25 \%$ increase in leaf greenness above control trees $(P<.0001$; Figure 1$)$.
Nitrogen and phosphorus bear some mention because, from a producer standpoint, both elements can be expensive farm inputs. Both elements are inherently low in fly ash [36] but can be quite elevated in biosolids. Because UAN applications were held constant for all fly ash and Fe EDDHA trees, as expected, all trees that received UAN had equal and higher soil $\mathrm{NO}_{3}-\mathrm{N}$ when compared to control soil $(P=$ .0004; Table 2). Except for the FA 44.5 rate, total leaf $\mathrm{N}$ was also equal and highest for trees receiving UAN (Figure 1; $P<.0001)$. Only the ACB 44.5 rate equaled this response, increasing $\mathrm{NO}_{3}-\mathrm{N}$ by $43 \%$ (Table 2 ) and plant $\mathrm{N}$ by $70 \%$ (Figure 1). The two lower composted biosolid rates were similar to the control for soil $\mathrm{NO}_{3}-\mathrm{N}$, but total plant $\mathrm{N}$ 
TABLE 3: Biomass results of OP-367 (P. deltoides $\times$ P. nigra) showing significant differences after amending with industrial byproducts. Means with the same letter are not significantly different at the $\alpha=$ 0.05 level.

\begin{tabular}{lcccc}
\hline & $\begin{array}{c}\text { Leaf area } \\
\left(\mathrm{cm}^{2}\right)\end{array}$ & $\begin{array}{c}\text { Leaf dry } \\
\text { weight } \\
(\mathrm{g})\end{array}$ & $\begin{array}{c}\text { Stem dry } \\
\text { weight } \\
(\mathrm{g})\end{array}$ & $\begin{array}{c}\text { Stem } \\
\text { length } \\
(\mathrm{cm})\end{array}$ \\
\hline Treatments ${ }^{\mathrm{a}}$ & $1419 \mathrm{~d}$ & $15.0 \mathrm{~b}$ & $14.0 \mathrm{~d}$ & $124.6 \mathrm{abc}$ \\
Fe EDDHA + & $1552 \mathrm{bc}$ & $15.1 \mathrm{~b}$ & $14.5 \mathrm{bcd}$ & $124.0 \mathrm{abc}$ \\
UAN & $1563 \mathrm{bc}$ & $16.4 \mathrm{a}$ & $15.6 \mathrm{abc}$ & $127.6 \mathrm{ab}$ \\
ACB DTPA & $1584 \mathrm{abc}$ & $16.4 \mathrm{a}$ & $16.1 \mathrm{a}$ & $129.4 \mathrm{a}$ \\
ACB 22.75 & $1464 \mathrm{~cd}$ & $15.2 \mathrm{~b}$ & $15.6 \mathrm{abc}$ & $126.3 \mathrm{ab}$ \\
ACB 44.5 & $1527 \mathrm{bcd}$ & $15.2 \mathrm{~b}$ & $14.3 \mathrm{~cd}$ & $122.5 \mathrm{bc}$ \\
FA 22.75 + UAN & $1694 \mathrm{a}$ & $16.1 \mathrm{ab}$ & $14.8 \mathrm{bcd}$ & $124.2 \mathrm{abc}$ \\
FA 44.5 + UAN & $1590 \mathrm{ab}$ & $15.3 \mathrm{ab}$ & $14.3 \mathrm{~cd}$ & $119.5 \mathrm{c}$ \\
FA DTPA + & 121 & 1.1 & 1.3 & 5.5 \\
UAN & 3.79 & 2.3 & 2.84 & 2.5 \\
\hline LSD & 0.002 & 0.0397 & 0.0133 & 0.0263 \\
$F$ Value & & &
\end{tabular}

${ }^{a}$ Refer to Experimental Design and Statistical Analysis section for treatment codes.

significantly increased by $27 \%$ in ACB-22.75-treated trees (Figure 1). Phosphorus contents of fly ash- and Fe EDDHAtreated soil were no different than the control (Table 2) because these trees received no supplemental P. On the other hand, P was $147-450 \%$ higher in soil treated with composted biosolids because Albuquerque uses iron chloride salts to remove $\mathrm{P}$ from the waste stream during the treatment process. This fact had some effect on soil salinity (more below).

3.1.2. Tree Growth. The following tree growth measurements were unaffected by the treatments: stem diameters (mean $10 \mathrm{~mm}$ ), root dry weights (mean $9.4 \mathrm{mg} \mathrm{kg}^{-1}$ ), total aboveground dry weights (mean $39.9 \mathrm{mg} \mathrm{kg}^{-1}$ ), and root-to-above ground-biomass ratios (mean 0.31; data not shown). Table 3 presents leaf area, leaf weight, stem weight, root weight, stem length, and stem diameter growth results. All treatments had greater leaf areas $(P=.0020)$ except for the FA $22.75 \mathrm{Mgha}^{-1}$, which compared equally to control trees (Table 3). The greatest leaf areas were from trees treated at the highest two fly ash application rates, followed by trees treated at the ACB $22.75 \mathrm{Mg} \mathrm{ha}^{-1}$ rate. For leaf dry weight, composted biosolids at the DTPA $\left(14 \mathrm{Mg} \mathrm{ha}^{-1}\right)$ and $22.75 \mathrm{Mg} \mathrm{ha}^{-1}$ rates had the greatest response followed by the FA 44.5 and FA DTPA + UAN treatments $(P=.0397$; Table 3); the Fe EDDHA + UAN and ACB $44.5 \mathrm{Mg} \mathrm{ha}^{-1}$ rates were no different than the control. For stem dry weight, biosolids at all rates had the greatest response compared to the control trees $(P=.0133)$; the control, Fe EDDHA, and fly ash plus UAN-treated trees were no different from one another (Table 3). Stem lengths were similar among the control soil, Fe EDDHA + UAN, composted biosolids, and FA $44.5 \mathrm{Mg} \mathrm{ha}^{-1}$ trees while the FA $22.75+$ UAN and FA
DTPA $\left(74 \mathrm{Mgha}^{-1}\right)$ rate had a nearly 2 and $4 \%$ reduction when compared to control tress $(P=.0263$; Table 3$)$.

Many complex factors influenced growth. Stem weights and stem lengths benefited from the added soil $\mathrm{Fe}$ while stem weights, stem lengths, and, to a lesser extent, stem diameters did not seem to benefit from the added $\mathrm{NO}_{3}-\mathrm{N}$ (Table 4). Increasing the soil salinity, $\mathrm{pH}$, and leaf $\mathrm{B}$ content also contributed to reduced growth (more below).

\subsection{Environmental Considerations}

3.2.1. Soil Sodium Adsorption Ratio, Electrical Conductivity, and $p H$. Salinity is a concern in our region because we average approximately $200 \mathrm{~mm}$ of rainfall per year, which equates to a low salt leaching potential. Any amendment containing high amounts of soluble salts poses the risk of increasing sodic/saline soil conditions. The sodium adsorption ratio (SAR) measures the proportion of $\mathrm{Na}^{+}$ions compared to the concentration of calcium $\mathrm{Ca}^{2+}$ plus $\mathrm{Mg}^{2+}$ in the saturated paste extract (the higher the SAR value, the more that $\mathrm{Na}^{+}$is dominating the soil chemistry). Electrical conductivity (EC) measures total soluble salt content (which can include $\mathrm{NaCl}$ but also N, P, Ca, Mg, and other fertilizer salts). An EC above 4 is generally considered the threshold point at which most agricultural crops suffer reduced yields [37].

When compared to the control, SAR values were similar for all treatments except for the ACB $44.5\left(4.95 \mathrm{mmol} \mathrm{L}^{-1}\right)$, which experienced a $12 \%$ reduction in values from the control soil $\left(5.65 \mathrm{mmol} \mathrm{L}^{-1} ; P<.0001\right.$; Table 5$)$. This is explained by the additional $\mathrm{Mg}$ and $\mathrm{Ca}$ contributions to the soil from the parent biosolids material (Table 1). All of the SAR values were considerably below $13-15 \mathrm{mmol} \mathrm{L}^{-1}$ which is considered sodic and problematic for agricultural soils. Still, an inverse association was found between increasing SAR values and stem weight $(r=-0.35 ; P=.0047)$ and stem length $(r=-0.26 ; P=.0389$; Table 4). Within plants, the ionic balance of $\mathrm{Ca}, \mathrm{Mg}, \mathrm{Na}$, components of the sodium adsorption ratio in soil, are known to be influenced by nitrogen fertilizer source [38]. The UAN may have had an effect on influencing the components of the SAR test and tree growth given the inverse relationship between $\mathrm{NO}_{3}-\mathrm{N}$ versus growth parameters shown in Table 4.

The Fe EDDHA, FA 22.75, and FA 44.5 + UAN treatments were similar to control soil for EC. However, soil treated at the FA DTPA + UAN $\left(74 \mathrm{Mg} \mathrm{ha}^{-1}\right)$ had a significant decrease in conductivity compared to control soil for reasons unknown. On the other hand, composted biosolid-treated soil increased EC by $21-41 \%$ above the control soil $(P<$ .0001; Table 5). The increase in EC was expected because biosolids are high in soluble salts. In fact, at the ACB $44.5 \mathrm{Mg} \mathrm{ha}^{-1}$ rate, EC reached $4 \mathrm{dS} \mathrm{m}^{-1}$. These levels were below the $5.5 \mathrm{dS} \mathrm{m}^{-1}$ tolerance limit defined for hybrid poplar [39] and did not appear to affect above-ground growth negatively (i.e., $r=0.27 ; P=.0279$ for the relationship between EC and stem length; Table 4). Although no significant relationship was demonstrated between EC and root weight $(r=-0.23 ; P=.0656$; Table 4$)$, the potential for decreasing this parameter with increasing salinity exists given 
TABle 4: Correlation matrix for 2005 Greenhouse Study showing growth versus soil and foliar parameter. Note: correlation coefficients $(r$ values) are followed by $P$ values; ** indicates significance $P<.05 ; * * *$ indicates significance $P<.001$.

\begin{tabular}{|c|c|c|c|c|c|c|}
\hline & Leaf area & Leaf Wt. & Stem Wt. & Root Wt. & Stem Lnth. & Stem Dia. \\
\hline \multirow{2}{*}{ Fe soil } & -0.08 & 0.09 & $0.42^{* * *}$ & -0.11 & $0.33^{* *}$ & 0.11 \\
\hline & 0.5197 & 0.4885 & 0.0006 & 0.3987 & 0.0068 & 0.4026 \\
\hline \multirow{2}{*}{ NO3-N } & -0.15 & -0.21 & $-0.45^{* * *}$ & -0.08 & $-0.46^{* * *}$ & $-0.28^{* *}$ \\
\hline & 0.2364 & 0.0983 & 0.0002 & 0.5246 & 0.0001 & 0.0234 \\
\hline \multirow{2}{*}{$\mathrm{pH}$} & -0.04 & -0.16 & $-0.54^{* * *}$ & -0.18 & $-0.41^{* * *}$ & -0.14 \\
\hline & 0.7443 & 0.1990 & $<0.0001$ & 0.1481 & 0.0007 & 0.2756 \\
\hline \multirow{2}{*}{ SAR } & 0.16 & -0.04 & $-0.35^{* *}$ & -0.14 & $-0.26^{* *}$ & -0.16 \\
\hline & 0.2213 & 0.7499 & 0.0047 & 0.2592 & 0.0389 & 0.1945 \\
\hline \multirow{2}{*}{$\mathrm{EC}$} & -0.14 & 0.08 & 0.24 & -0.23 & $0.27^{* *}$ & -0.04 \\
\hline & 0.2900 & 0.5548 & 0.052 & 0.0656 & 0.0279 & 0.7498 \\
\hline \multirow{2}{*}{ B leaves } & 0.21 & -0.08 & -0.20 & 0.14 & $-0.44^{* * *}$ & 0.03 \\
\hline & 0.0982 & 0.5331 & 0.1198 & 0.2605 & 0.0003 & 0.7922 \\
\hline
\end{tabular}

TABLE 5: Soil sodium adsorption ratio (SAR), electrical conductivity (salinity), and $\mathrm{pH}$ of a Doak sandy loam amended with industrial byproducts.

\begin{tabular}{lccc}
\hline & $\begin{array}{c}\text { SAR } \\
\text { Treatments }^{\mathrm{a}}\end{array}$ & $\begin{array}{c}\mathrm{EC} \\
\left(\mathrm{mmol} \mathrm{L}^{-1}\right)\end{array}$ & $\begin{array}{c}\mathrm{pH} \\
\left(\mathrm{dS} \mathrm{m}^{-1}\right)\end{array}$ \\
\hline Control & $5.65 \mathrm{ab}$ & $3.24 \mathrm{~d}$ & $8.62 \mathrm{~b}$ \\
Fe EDDHA + & $5.78 \mathrm{a}$ & $3.17 \mathrm{~d}$ & $8.66 \mathrm{ab}$ \\
UAN & $5.42 \mathrm{~b}$ & $3.47 \mathrm{c}$ & $8.58 \mathrm{bc}$ \\
ACB DTPA & $5.55 \mathrm{ab}$ & $3.77 \mathrm{~b}$ & $8.50 \mathrm{~cd}$ \\
ACB 22.75 & $4.95 \mathrm{c}$ & $4.04 \mathrm{a}$ & $8.44 \mathrm{~d}$ \\
ACB 44.5 & $5.73 \mathrm{a}$ & $3.10 \mathrm{de}$ & $8.64 \mathrm{~b}$ \\
FA 22.75 + UAN & $5.62 \mathrm{ab}$ & $3.16 \mathrm{~d}$ & $8.67 \mathrm{ab}$ \\
FA 44.5 + UAN & $5.67 \mathrm{a}$ & $3.03 \mathrm{e}$ & $8.76 \mathrm{a}$ \\
FA DTPA + UAN & 5.54 & 3.37 & 8.6 \\
Mean & 0.24 & 0.18 & 0.1 \\
LSD & 9.32 & 31.71 & 7.33 \\
$F$ Value & $<0.0001$ & $<0.0001$ & $<0.0001$ \\
Pr $>F$ &
\end{tabular}

${ }^{a}$ Refer to Experimental Design and Statistical Analysis section for treatment codes.

that containers were not leached. In later field plot studies, we found no salinity increases in plots amended with composted biosolids at $44 \mathrm{Mgha}^{-1}$ [40]. In the latter study, a total of $983 \mathrm{~mm}$ of water (irrigation + rainfall) was applied during the second growing season alone, which provided sufficient leaching potential; all biosolids field plots never exceeded an EC of $1 \mathrm{dS} \mathrm{m}^{-1}$ when sampled at a depth of $30 \mathrm{~cm}$.

Another concern is applying an amendment that may have the potential to raise soil $\mathrm{pH}$ in already calcareous conditions. The $\mathrm{pH}$ ranged from 8.4 in soil treated at the ACB $22.75 \mathrm{Mg} \mathrm{ha}^{-1}$ rate to 8.8 in the FA DTPA + UAN-treated soil (equivalent of $74 \mathrm{Mg} \mathrm{ha}^{-1}$ ); the control soil had a $\mathrm{pH}$ of 8.6 $(P<.0001$; Table 5$)$. Low S-containing western US lignite coals typically produce alkaline ash $[9,41]$, which explains the $\mathrm{pH}$ increase in accordance with increasing application rate of fly ash. The $\mathrm{pH}$ increase was related to a reduction in stem weights $(r=-0.54 ; P<.0001)$ and stem length $(r=-0.41 ; P=.0007)$, and the general trend was that as $\mathrm{pH}$ increased, leaf area, leaf weight, root weight, and stem diameter decreased (Table 4).

Composted biosolids, when applied at the $22.75 \mathrm{Mg} \mathrm{ha}^{-1}$ rate, decreased $\mathrm{pH}$ below the control soil to 8.4. As salt concentration increases, soluble cations, such as $\mathrm{Ca}^{2+}$ and $\mathrm{Mg}^{2+}$, replace acidic exchangeable cations $\left(\mathrm{H}^{+}\right.$and $\left.\mathrm{Al}^{3+}\right)$ in the soil solution, lowering the $\mathrm{pH}$ of the soil extract solution $[35,43,44]$. The reduction in $\mathrm{pH}$ was probably related to the soluble salt content of the material. In field studies with the same biosolid application rates as in this study, under a leaching fraction, soil $\mathrm{pH}$ was equal among biosolid treatment [40].

3.2.2. Other Environmental Considerations. The following metals were analyzed in soils from acid digests: Cr, As, $\mathrm{Ag}, \mathrm{Se}, \mathrm{Pb}, \mathrm{Cd}$, and $\mathrm{Ba}$. Arsenic, $\mathrm{Ag}$, and Se were not detected in either soils or plants. Lead, $\mathrm{Cr}$, and $\mathrm{Cd}$ also did not increase in soils in either study, averaging $7.71 \mathrm{mg} \mathrm{kg}^{-1}$ for $\mathrm{Cr}, 5.08 \mathrm{mg} \mathrm{kg}^{-1}$ for $\mathrm{Pb}$, and $0.16 \mathrm{mg} \mathrm{kg}^{-1}$ for $\mathrm{Cd}$ (Table 6). These levels were below USEPA (Part 503 Rule) and European Union (Directive 86/278/EEC) regulations for heavy metal loading rates for biosolids applied to agricultural lands [42].

Boron and $\mathrm{Ba}$, however, did present potential environmental concerns. Boron increased in the leaves of fly ash + UAN amended poplars by $23 \%\left(22.75 \mathrm{Mgha}^{-1}\right.$ rate $)$, $45 \%$ (44.5 $\mathrm{Mgha}^{-1}$ rate) to $85 \%$ (rate equivalent to $74 \mathrm{Mgha}^{-1}$ ) (Figure 2). Although $\mathrm{B}$ is a micronutrient needed by plants in trace amounts, toxicity symptoms and decreased crop yields result from the application of unweathered fly ash $[9,41,45,46]$. At the highest fly ash application rate, leaf $\mathrm{B}$ reached $93.6 \mathrm{mg} \mathrm{kg}^{-1}$, which began to approach toxicity levels (above $141 \mathrm{mg} \mathrm{B} \mathrm{kg}^{-1} \mathrm{dwt}$ ) defined for OP-367 by Bañuelos et al. [47]. Indeed, the elevated B levels found in the leaves of fly ash-treated trees inversely correlated with stem lengths $(r=-0.44 ; P=.0003$; Table 4$)$. As B moves 
TABle 6: Soil Cr, Pb, Ba, and Cd levels in a Doak sandy loam amended with industrial byproducts.

\begin{tabular}{lcccc}
\hline & $\begin{array}{c}\mathrm{Cr} \\
\left(\mathrm{mg} \mathrm{kg}^{-1}\right)\end{array}$ & $\begin{array}{c}\mathrm{Pb} \\
\left(\mathrm{mg} \mathrm{kg}^{-1}\right)\end{array}$ & $\begin{array}{c}\mathrm{Ba} \\
\left(\mathrm{mg} \mathrm{kg}^{-1}\right)\end{array}$ & $\begin{array}{c}\mathrm{Cd} \\
\left(\mathrm{mg} \mathrm{kg}^{-1}\right)\end{array}$ \\
\hline $\begin{array}{l}\text { Literature } \\
\text { U.S. EPA 40 CFR }\end{array}$ & - & 300.0 & - & 39.00 \\
503 Rule & & & \\
European Union & - & $750-1,200$ & - & $20-40$ \\
limit values & & & & \\
EU proposed $^{\mathrm{b}}$ & 1000.0 & 750.0 & - & 10.00 \\
\hline Treatments & & & & \\
Control & $7.28 \mathrm{a}$ & $5.19 \mathrm{a}$ & $97.23 \mathrm{e}$ & $0.16 \mathrm{a}$ \\
Fe EDDHA + UAN & $7.60 \mathrm{a}$ & $5.19 \mathrm{a}$ & $98.18 \mathrm{de}$ & $0.17 \mathrm{a}$ \\
ACB DTPA & $8.34 \mathrm{a}$ & $5.07 \mathrm{a}$ & $105.83 \mathrm{~cd}$ & $0.16 \mathrm{a}$ \\
ACB 22.75 & $7.80 \mathrm{a}$ & $5.05 \mathrm{a}$ & $102.33 \mathrm{de}$ & $0.15 \mathrm{a}$ \\
ACB 44.5 & $7.92 \mathrm{a}$ & $5.12 \mathrm{a}$ & $100.84 \mathrm{de}$ & $0.17 \mathrm{a}$ \\
FA 22.75 + UAN & $7.68 \mathrm{a}$ & $5.22 \mathrm{a}$ & $111.48 \mathrm{bc}$ & $0.17 \mathrm{a}$ \\
FA 44.50 + UAN & $7.51 \mathrm{a}$ & $4.93 \mathrm{a}$ & $119.25 \mathrm{~b}$ & $0.17 \mathrm{a}$ \\
FA DTPA + UAN & $7.53 \mathrm{a}$ & $4.86 \mathrm{a}$ & $137.63 \mathrm{a}$ & $0.17 \mathrm{a}$ \\
\hline Mean & 7.71 & 5.08 & 109.10 & 0.16 \\
LSD & NS & NS & 8.46 & NS \\
F Value & 0.34 & 1.02 & 20.93 & 0.95 \\
Pr $>$ F & 0.9302 & 0.4274 & $<.0001$ & 0.48 \\
\hline
\end{tabular}

a Pollutant concentration limits and loading rates for land application in the United States.

${ }^{b}$ European Union limit values for concentrations of heavy metals in biosolids for use on land [42].

${ }^{\mathrm{c}}$ Refer to Experimental Design and Statistical Analysis section for treatment codes.

easily with irrigation waters, accumulation of B may have been mitigated if the containers were leached. Thus, boron accumulations to toxic levels present an environmental concern for agricultural land application of fly ash to our soils if not leached regularly and managed carefully.

Barium increased $7-42 \%$ in fly ash-amended soil (Table 6). As a consequence, the stem and leaf Ba levels combined increased $60-110 \%$ (46.3-60.8 $\mathrm{mg} \mathrm{kg}^{-1}$ ) compared to control trees $\left(28.9 \mathrm{mg} \mathrm{kg}^{-1} ; P<.0001\right.$; Figure 2). The increase of $\mathrm{Ba}$ is not uncommon when fly ash is applied to land [46]. With regards to $\mathrm{Ba}$, it is difficult to assume environmental safety because we did not analyze for potentially toxic forms (barium carbonate, barium chloride, and barium acetate) [48].

As for the composted biosolids material or the composted biosolid/soil mixtures, we did not analyze for the presence of antibiotics and/or personal care products. Recent attention to these persistent organic constituents shows that biosolids, especially when not composted, may impart potential antibiotic resistance in soil micro-organisms or molecules from personal care products may exhibit hormonal effects on aquatic organisms [14, 49]. Although the risk factors associated with antibiotics and personal care products can be mitigated by composting [49, 50], an analysis for these constituents is essential to strengthening our knowledge of the material used in this study and

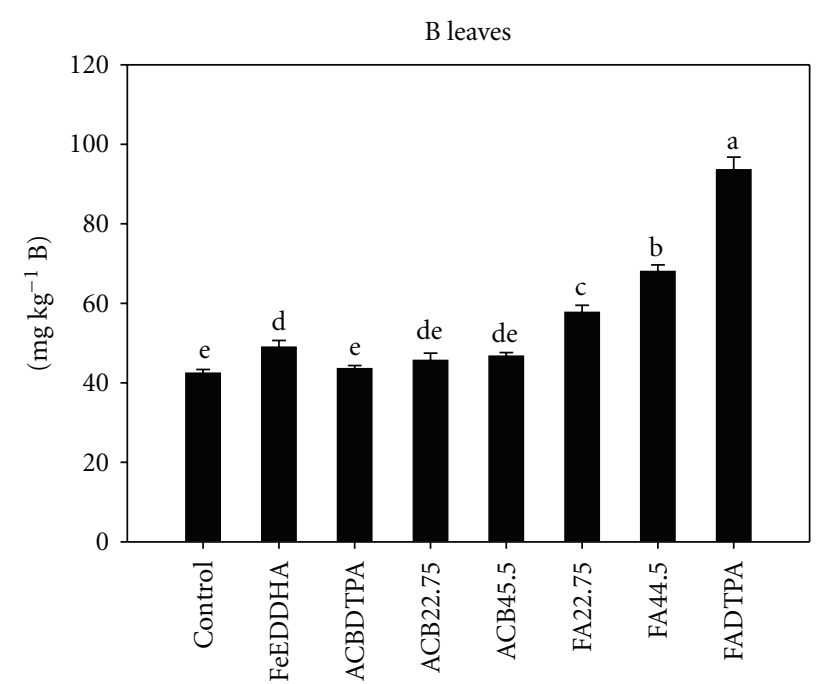

(a)

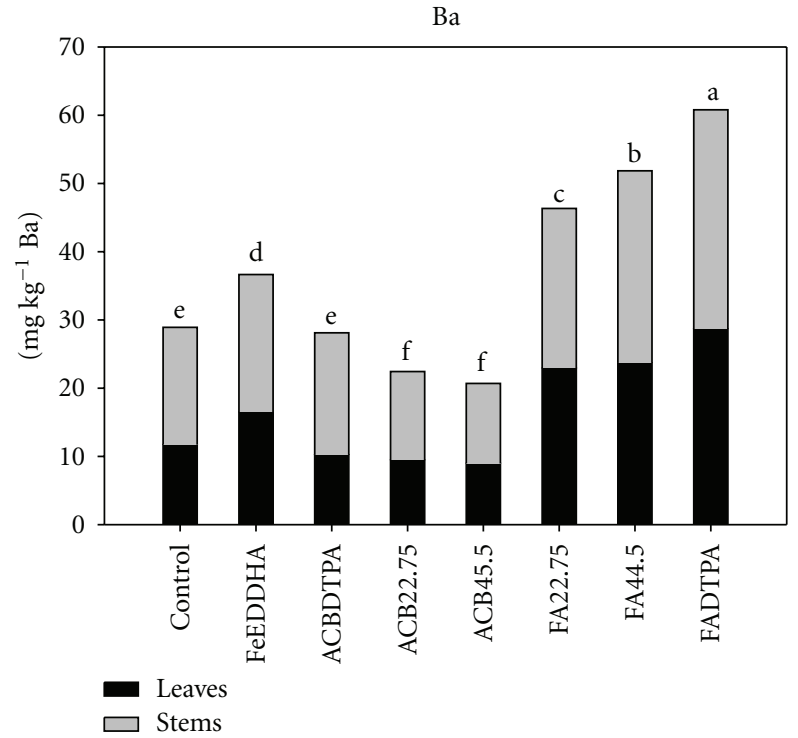

(b)

Figure 2: Leaf B (a) and leaf + stem Ba (b) of the hybrid poplar clone OP-367 cultivated in soil amended with Fe EDDHA + UAN (urea ammonium nitrate), fly ash + UAN, and composted biosolids. Means with the same letter are not significantly different at $\alpha=0.05$ level for combined leaf and stem material. Refer to Experimental Design and Statistical Analysis section for treatment codes.

in developing a future comprehensive environmental risk assessment when composted biosolids might be considered for agricultural land application.

\section{Conclusions}

The Fe EDDHA + UAN had the highest SPAD values and plant Fe (stem+leaves). This is an expensive synthetic fertilizer input with $6 \%$ plant-available iron. In comparison, fly ash plus UAN significantly increased SPAD values and plant Fe in hybrid poplars even though soil Fe remained 
statistically similar to the control soil. The trend in SPAD values and plant $\mathrm{Fe}$ generally followed fly ash application rate- the higher the rate, the greater the response. Despite the increase in soil $\mathrm{pH}$ from fly ash additions, which would imply even lower solubility of micronutrients, and the fact that $\mathrm{N}$ from UAN remained constant among the fly ash (and Fe EDDHA treatments), the uptake of Fe in fly ashamended poplars was likely related to an acidulation of the rhizosphere from UAN applications which made Fe more available just at the root/soil interface. Leaf area was greatest in hybrid poplar trees grown in soil amended with fly ash treatments, but growth was similar to the control for all other biometric parameters. The highest plant $\mathrm{B}$ accumulations occurred in the fly ash + UAN treatments, especially at the fly ash rate equivalent to $74 \mathrm{Mg} \mathrm{ha}^{-1}$. Increasing leaf B was inversely associated with stem length in these trees. Stem and leaf $\mathrm{Ba}$ was also highest in trees grown in fly ash-treated soil. Potentially toxic forms of Ba found in fly ash were not measured, which warrants further investigation. Finally, the fact that $\mathrm{NO}_{3}-\mathrm{N}$ was inversely related to growth raises the need for us to conduct a UAN exclusion study before a definitive recommendation can be made concerning fly ash applications to agricultural lands.

Biosolids significantly increased soil Fe and $\mathrm{P}$ in all treatments, and $\mathrm{NO}_{3}-\mathrm{N}$ only at the $44.5 \mathrm{Mg} \mathrm{ha}^{-1}$ rate. Although lower than the Fe EDDHA treatment, composted biosolidtreated trees had SPAD and plant Fe values significantly increase in proportion to application rate, showing that composted biosolids could supply plant-available Fe to trees growing on an alkaline soil. Likewise, total plant $\mathrm{N}$ increased, but only the $44.5 \mathrm{Mg} \mathrm{ha}^{-1}$ treatment equaled the response of UAN-treated trees. Trees grown under composted biosolids applied at the DTPA $\left(14 \mathrm{Mg} \mathrm{ha}^{-1}\right)$ and $22.75 \mathrm{Mg} \mathrm{ha}^{-1}$ rates generally had the highest growth (stem dry weight, stem length, and leaf dry weight). Saturated paste extracts of the byproducts demonstrated that composted biosolids had the most potential for increasing soil salinity due to their complex mixtures of soluble salts. Soil treated with the $44.5 \mathrm{Mgha}^{-1}$ rate had an EC of $4 \mathrm{dS} \mathrm{m}^{-1}$ which may explain why the lower biosolids application rates generally had greater tree growth. An inverse relationship between increasing salinity and decreasing root dry weight was shown, but salinity increases were below tolerance levels defined for hybrid poplar, and salts would be flushed from the root zone if leaching of containers was allowed in this study.

Overall, trees grown under biosolids generally exhibited the greatest response in regards to growth, soil, and plant $\mathrm{Fe}$, $\mathrm{N}$, and $\mathrm{P}$ increases without the need to provide supplemental $\mathrm{N}$ nutrition in the form of UAN. Other benefits not reported included an increase in $\mathrm{Zn}, \mathrm{Cu}$, and $\mathrm{Mn}$ in trees grown with composted biosolid amended soil. Amendment/soil mixtures showed little potential for environmental hazard in terms of heavy metal increases. It appears that a onetime application of the ACB $22.75 \mathrm{Mg} \mathrm{ha}^{-1}$ rate is sufficient to supply plantavailable Fe and growth benefits to hybrid poplar seedlings without the risk of increasing salinity in unleached circumstances. The beneficial recycling of nutrients from biosolids to agricultural crops produced on a calcareous soil is feasible.
An analysis of the Albuquerque composted biosolids for antibiotics and personal care products would add value to future field plot studies.

\section{Acknowledgments}

The authors would like to thank the U.S. Department of Energy National Energy Technology Laboratory and the Combustion Byproducts Recycling Consortium for partial funding of this paper. The authors wish to thank Steven Glass, City of Albuquerque, for donating the composted biosolids and Bruce Salisbury, Arizona Public Services, for the fly ash.

\section{References}

[1] R. H. Loeppert, L.-C. Wei, and W. R. Ocumpaugh, "Soil factors influencing the mobilization of iron in calcareous soils," in Biochemistry of Metal Micronutrients in the Rhizosphere, J. A. Manthey, D. E. Crowley, and D. G. Luster, Eds., pp. 343360, CRC Press, Boca Raton, Fla, USA, 1994.

[2] B. L. Black and R. H. Zimmerman, "Mixtures of coal ash and compost as substrates for highbush blueberry," Journal of the American Society for Horticultural Science, vol. 127, no. 5, pp. 869-877, 2002.

[3] M. A. Cavaleri, D. W. Gilmore, M. Mozaffari, C. J. Rosen, and T. R. Halbach, "Hybrid poplar and forest soil response to municipal and industrial by products: a greenhouse study," Journal of Environmental Quality, vol. 33, no. 3, pp. 10551061, 2004.

[4] R. F. Korcak, "Utilization of coal combustion by-products in agriculture and horticulture," in Agricultural Utilization of Urban and Industrial By-Products, pp. 107-130, American Society of Agronomy: Crop Science Society of America: Soil Science Society of America, Madison, Wis, USA, 1995.

[5] P. U. Sashee Kumar and S. Sambath Kumar, "Fly ash: potential applications," Chemical Engineering World, vol. 37, no. 2, pp. 83-85, 2002.

[6] R. Moral, J. Moreno-Caselles, M. Perez-Murcia, and A. PerezEspinosa, "Improving the micronutrient availability in calcareous soils by sewage sludge amendment," Communications in Soil Science and Plant Analysis, vol. 33, no. 15-18, pp. 30153022, 2002.

[7] P. Parkpian, S. T. Leong, P. Laortanakul, and J. Juntaramitree, "An environmentally sound method for disposal of both ash and sludge wastes by mixing with soil: a case study of Bangkok plain," Environmental Monitoring and Assessment, vol. 74, no. 1, pp. 27-43, 2002.

[8] American Coal Ash Association, "Glossary of terms concerning the management and use of coal combustion products (CCPs)," 2003, http://www.acaa-usa.org/.

[9] C. L. Carlson and D. C. Adriano, "Environmental impacts of coal combustion residues," Journal of Environmental Quality, vol. 22, no. 2, pp. 227-247, 1993.

[10] G. W. Dickerson, A Sustainable Approach to Recycling Urban and Agricultural Organic Wastes, New Mexico State University Cooperative Extension Service, Las Cruces, NM, USA, 2000.

[11] G. M. Zinati, Y. Li, and H. H. Bryan, "Accumulation and fractionation of copper, iron, manganese, and zinc in calcareous soils amended with composts," Journal of Environmental Science and Health Part B, vol. 36, no. 2, pp. 229-243, 2001. 
[12] C. M. Cooke, L. Gove, F. A. Nicholson, H. F. Cook, and A. J. Beck, "Effect of drying and composting biosolids on the movement of nitrate and phosphate through repacked soil columns under steady-state hydrological conditions," Chemosphere, vol. 44, no. 4, pp. 797-804, 2001.

[13] K. Bousselhaj, S. Fars, A. Laghmari, A. Nejmeddine, N. Ouazzani, and C. Ciavatta, "Nitrogen fertilizer value of sewage sludge co-composts," Agronomie, vol. 24, no. 8, pp. 487-492, 2004.

[14] W. F. Jaynes and R. E. Zartman, "Origin of talc, iron phosphates, and other minerals in biosolids," Soil Science Society of America Journal, vol. 69, no. 4, pp. 1047-1056, 2005.

[15] BNR Operation in Wastewater Treatment Plants Task Force, Biological Nutrient Removal Operation in Wastewater Treatment Plants, Water Environment Federation and American Society of Civil Engineers and Environmental and Water Resources Institute, Eds., McGraw-Hill, New York, NY, USA, 2005.

[16] City of Albuquerque, “ Compost Facility Operations," 2008, http://www.abcwua.org/content/view/197/350/.

[17] A. Dellantonio, W. J. Fitz, H. Custovic et al., "Environmental risks of farmed and barren alkaline coal ash landfills in Tuzla, Bosnia and Herzegovina," Environmental Pollution, vol. 153, no. 3, pp. 677-686, 2008.

[18] R. J. Haynes, "Reclamation and revegetation of fly ash disposal sites-challenges and research needs," Journal of Environmental Management, vol. 90, no. 1, pp. 43-53, 2009.

[19] WU. Chenxi, A. L. Spongberg, and J. D. Witter, "Determination of the persistence of pharmaceuticals in biosolids using liquid-chromatography tandem mass spectrometry," Chemosphere, vol. 73, no. 4, pp. 511-518, 2008.

[20] J. A. Ippolito, K. A. Barbarick, M. W. Paschke, and R. B. Brobst, "Infrequent composted biosolids applications affect semiarid grassland soils and vegetation," Journal of Environmental Management, vol. 91, no. 5, pp. 1123-1130, 2010.

[21] C. W. Keetch, Soil survey of San Juan County New Mexico: Eastern Part.: USDA SCS, USDA BIA and BOR, NMSU Agricultural Experiment Station, 1980.

[22] C. Jones and J. Jacobsen, "Micronutrients: cycling, testing and fertilizer recommendations," in Nutrient Management, a Self-Study Course from the MSU Extension Service Continuing Education Series, Montana State University, 2003.

[23] W. C. Dahnke, "Use of the nitrate specific ion electrode in soil testing," Communications in Soil Science and Plant Analysis, vol. 2, no. 2, pp. 73-84, 1971.

[24] J. S. Schepers, T. M. Blackmer, and D. D. Francis, "Chlorophyll meter method for estimating nitrogen content in plant tissue," in Handbook of Reference Methods for Plant Analysis, Y. P. Kalra, Ed., pp. 129-134, CRC Press, Boca Raton, Fla, USA, 1998.

[25] K. Lombard, M. O’Neill, J. Mexal et al., “Can soil plant analysis development values predict chlorophyll and total Fe in hybrid poplar?” Agroforestry Systems, vol. 78, no. 1, pp. 1-11, 2009.

[26] C. R. Campbell and C. O. Plank, "Preparation of plant tissue for laboratory analysis," in Handbook of Reference Methods for Plant Analysis, Y. P. Kalra, Ed., pp. 37-49, CRC Press, Boca Raton, Fla, USA, 1998.

[27] D. E. Baker, G. W. Gorsline, C. G. Smith, W. I. Thomas, W. E. Grube, and J. L. Ragland, "P, K, Ca, Mg, Na, B, Zn, Mn, $\mathrm{Fe}, \mathrm{Cu}$, and Mo of botanical materials (dry ash)," Agronomy Journal, vol. 56, pp. 133-136, 1964.

[28] R. O. Miller, "Microwave digestion of plant tissue in a closed vessel," in Handbook of Reference Methods for Plant Analysis, Y. P. Karla, Ed., pp. 69-73, CRC Press, New York, NY, USA, 1998.
[29] P. N. Soltanpour and A. P. Schwab, "A new soil test for simultaneous extraction of macro-and micro-nutrients in alkaline soils," Communications in Soil Science and Plant Analysis, vol. 8, pp. 195-207, 1977.

[30] USEPA, Microwave assisted acid digestion of sediments, sludges, soils, and oils, US Environmental Protection Agency, Washington, DC, USA, 1998.

[31] R. C. Littell, W. W. Stroup, and R. J. Freund, SAS for Linear Models, SAS Institute, Cary, NC, USA, 4th edition, 2002.

[32] L. H. Weinstein, M. A. Arthur, R. E. Schneider et al., "Uptake of chemical elements by terrestrial plants growing on a coal fly ash landfill," in Trace Elements in Coal and Coal Combustion Residues, R. F. Keefer and K. S. Sajwan, Eds., pp. 213-237, CRC Press, Boca Raton, Fla, USA, 1993.

[33] V. D. Fageria, "Nutrient interactions in crop plants," Journal of Plant Nutrition, vol. 24, no. 8, pp. 1269-1290, 2001.

[34] H. M. Reisenauer, "The interactions of manganese and iron," in Biochemistry of Metal Micronutrients in the Rhizosphere, J. A. Manthey, D. E. Crowley, and D. G. Luster, Eds., pp. 147-164, CRC Press, Boca Raton, Fla, USA, 1994.

[35] S. L. Tisdale, W. L. Nelson, and J. D. Beaton, Soil Fertility and Fertilizers, Macmillan Publishing Company, New York, NY, USA, 4th edition, 1985.

[36] D. K. Gupta, U. N. Rai, R. D. Tripathi, and M. Inouhe, "Impacts of fly-ash on soil and plant responses," Journal of Plant Research, vol. 115, no. 6, pp. 401-409, 2002.

[37] E. V. Maas and G. J. Hoffman, "Crop salt tolerance-current assessment," Journal of the Irrigation and Drainage Division, vol. 103, pp. 115-134, 1977.

[38] E. A. Kirkby and K. Mengel, "Ionic balance in different tissues of the tomato plant in relationship to nitrate, urea, or ammonium nutrition," Plant Physiology, vol. 42, pp. 6-14, 1967.

[39] M. C. Shannon, G. S. Bañuelos, J. H. Draper, H. Ajwa, J. Jordahl, and L. Licht, "Tolerance of hybrid poplar (Populus) trees irrigated with varied levels of salt, selenium, and boron," International Journal of Phytoremediation, vol. 1, no. 3, pp. 273-288, 1999.

[40] K. Lombard, M. O’Neill, R. Heyduck et al., “Composted biosolids as a source of iron for hybrid poplars (Populus sp.) grown in northwest New Mexico," Agroforestry Systems, vol. 81, no. 1, pp. 45-56, 2011.

[41] M. P. Menon, K. S. Sajwan, G. S. Ghuman, J. James, and K. Chandra, "Elements in coal and coal ash residues and their potential for agricultural crops," in Trace Elements in Coal and Coal Combustion Residues, R. F. Keefer and K. S. Sajwan, Eds., pp. 259-287, CRC Press, Boca Raton, Fla, USA, 1993.

[42] National Research Council, "Committee on Toxicants and Pathogens in Biosolids Applied to Land," in Biosolids Applied to Land: Advancing Standards and Practices, National Research Council, Board on Environmental Studies and Toxicology, Washington DC, USA, 2002.

[43] A. S. Al-Busaidi and P. Cookson, "Salinity-pH relationships in calcareous soils," Agricultural and Marine Sciences, vol. 8, no. 1, pp. 41-46, 2003.

[44] NRCS, "Use of reaction (pH) in soil taxonomy," 1993, http:// soils.usda.gov/technical/technotes/note8.html.

[45] W. A. Dick, L. Chen, and Y. Hao, "Beneficial uses of clean coal combustion by-products: soil amendment and coal refuse treatment examples and case studies," 2000, http://www. mcrcc.osmre.gov/MCR/Resources/ccb/PDF/Use_and_Disposal_of_CCBs_at_Coal_Mines.pdf\#page=155.

[46] A. P. Schwab, "Extractable and plant concentrations of metals in amended coal ash," in Trace Elements in Coal and Coal 
Combustion Residues, R. F. Keefer and K. S. Sajwan, Eds., pp. 185-211, CRC Press, Boca Raton, Fla, USA, 1993.

[47] G. S. Bañuelos, M. C. Shannon, H. Ajwa, J. H. Draper, J. Jordahl, and L. Licht, "Phytoextraction and accumulation of boron and selenium by poplar (Populus) hybrid clones," International Journal of Phytoremediation, vol. 1, no. 1, pp. 81-96, 1999.

[48] E. Apedaile, "CH2M Hill Canada Limited, and D. Cole, 2002. Health aspects of biosolids land application," A report prepared for the City of Ottawa: Ottawa, Canada.

[49] K. Xia, A. Bhandari, K. Das, and G. Pillar, "Occurrence and fate of pharmaceuticals and personal care products (PPCPs) in biosolids," Journal of Environmental Quality, vol. 34, no. 1, pp. 91-104, 2005.

[50] H. Dolliver, S. Gupta, and S. Noll, "Antibiotic degradation during manure composting," Journal of Environmental Quality, vol. 37, no. 3, pp. 1245-1253, 2008. 

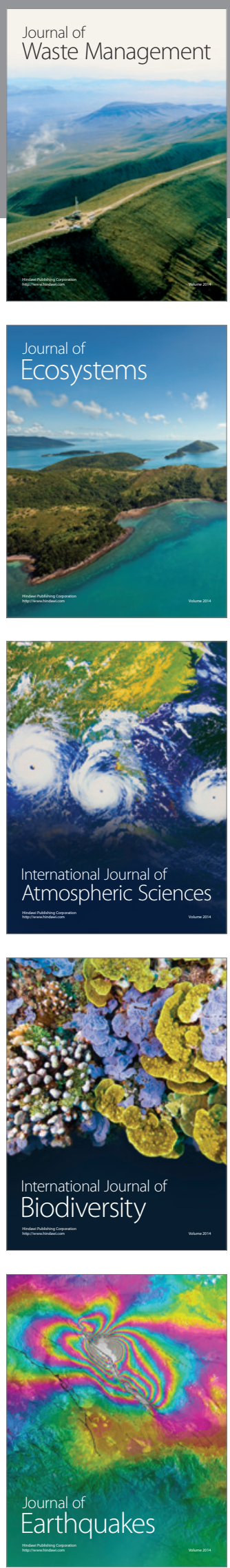
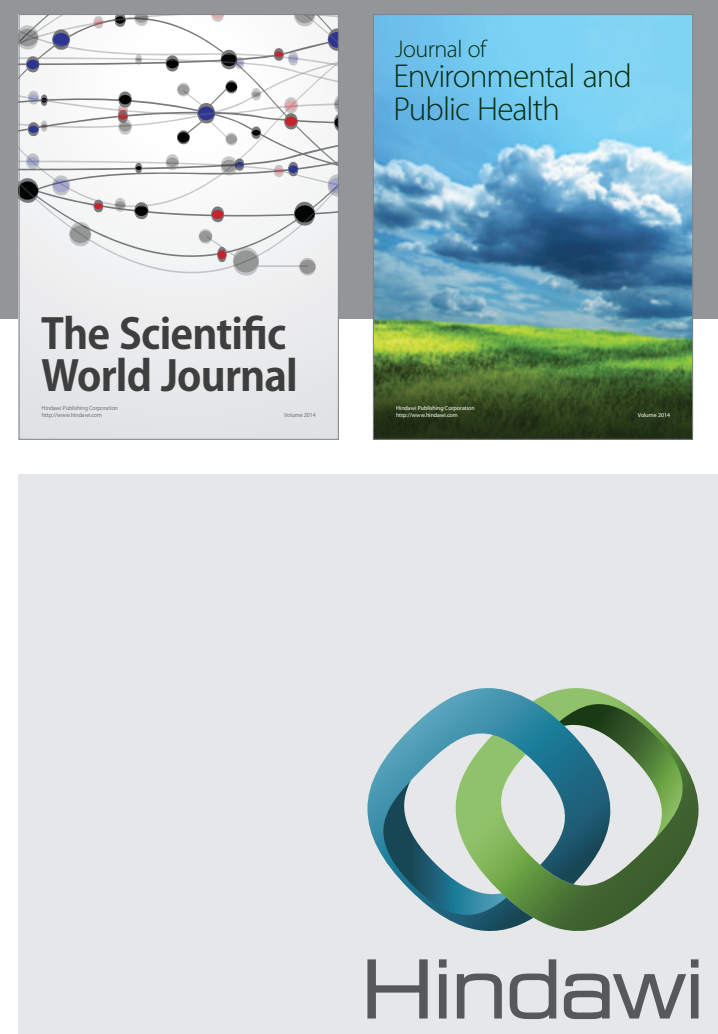

Submit your manuscripts at

http://www.hindawi.com
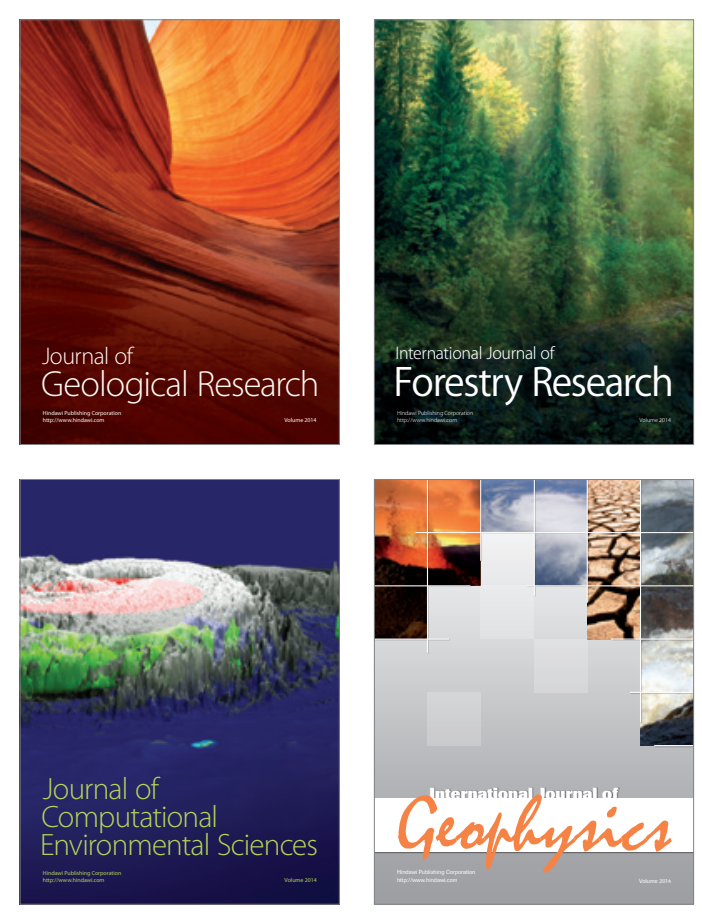
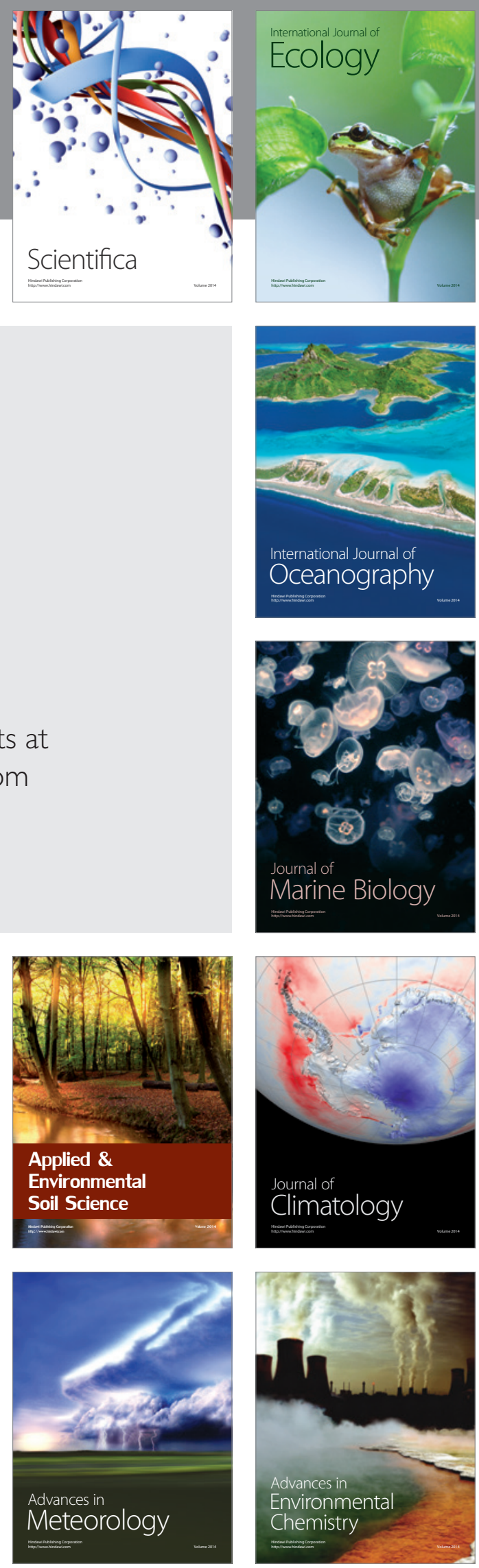